\title{
Influence of production systems on the properties of fresh and hardened shotcrete
}

\author{
Influência do sistema de produção em propriedades no \\ estado fresco e endurecido de argamassas projetadas
}

\section{Gabriela Cechin \\ Carina Mariane Stolz \\ Angela Borges Masuero}

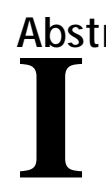

Abstract

n modern shotcrete operations, the mixing and pumping steps are carried out using different production systems and equipment. This adds an element of uncertainty to the process because of variables such as mixer type, rotation speed, mixing time, etc. As a result, this may result in changes to the characteristics and properties of both fresh and hardened sprayed mortar and may ultimately impair the performance of the rendering material. This study assesses the influence of production systems, particularly the mixing process, on the properties of fresh and hardened sprayed mortar. The methods used comprehend the collection and testing of mortar samples produced in wet-mix and dry-mix shotcrete systems, as well as a pre-packaged mortar batched and mixed in a laboratory mixer under controlled conditions according to the manufacturer's instructions. Results were processed using analysis of variance (ANOVA) and multiple comparison of means using Fisher's method. A statistically significant difference was observed in the flow table index, water retention, flexural strength and capillarity coefficient of the mortars produced using wet- and dry-mix systems.

Keywords: Shotcrete. Shotcrete equipment. Production systems. Sprayed mortar.

\section{Resumo}

No atual processo de projeção de argamassas, as etapas de mistura e bombeamento envolvem distintos sistemas de produção e equipamentos disponíveis no mercado. Este fato insere variabilidade no processo, devido a diferentes circunstâncias, tais como: tipo de misturador, velocidade de rotação, tempo de mistura, entre outras. Em consequência disso, as características e propriedades das argamassas, tanto no estado fresco como no endurecido, são distintas, podendo impactar em uma perda de desempenho do revestimento. Nesse contexto, o presente trabalho tem como objetivo verificar a influência do sistema de produção, mais

Gabriela Cechin Universidade Federal do Rio Grande do Sul Porto Alegre - RS - Brasil

Carina Mariane Stolz Universidade Feevale Novo Hamburgo - RS - Brasil

Ângela Borges Masuero Universidade Federal do Rio Grande

do Sul

Porto Alegre - RS - Brasil

Recebido em 17/04/17

Aceito em 15/12/17 especificadamente o processo de mistura, nas propriedades, do estado fresco e endurecido, de argamassas para projeção. Para tanto, a metodologia aplicada compreende coletas e ensaios nas argamassas produzidas em sistemas distintos de produção: central misturadora portátil (com abastecimento por bombeamento via seca), central misturadora fixa (com abastecimento por via úmida) e argamassa produzida em argamassadeira, com controle de laboratório e dosagem conforme recomendação do fabricante. Através da análise de variância (ANOVA) e análise múltipla de médias, pelo método de Fisher, dos resultados, verificou-se uma diferença estatisticamente significativa no índice de consistência, retenção de água, resistência à tração na flexão e coeficiente de capilaridade das argamassas produzidas em diferentes equipamentos.

Palavras-chaves: Projeção. Equipamento de projeção. Sistemas de produção. Argamassa projetada. 


\section{Introduction}

In Brazil, nearly all residential buildings use rendering mortars in facades as a substrate for paints or other types of surface finish (BRITEZ, 2007).

To fulfill their role, rendering mortars need to have specific properties, both in the fresh and the hardened state. Such properties depend on the characteristics of their constituents, the ratio between them, the mixing process used and the method used to apply the render, as well as on the nature of the substrate and environmental conditions (COSTA, 2005). The main performance requirements that the rendering mortar must meet in the fresh state are mass density, entrained air content, workability, water retention, bond strength and slump. In the hardened state, it is important to assess permeability, shrinkage, ability to withstand strain, adherence and mechanical strength (SELMO, 1989; CARNEIRO, 1993; CINCOTTO; SILVA; CARASEK, 1995; BAÍA; SABBATINI, 2000).

There are several operations and variables in the sprayed mortar production process that do not receive due attention and that may impair the performance of the material. The production of a rendering mortar involves many steps, such as the preparation of cost estimates, the placement of orders, the receipt and storage of materials and the production steps themselves, which require materials to be transported, mixed and applied, including spraying and leveling operations (MASSETTO et al.,1998).

From the late 1980s, the production of rendering mortars has been in permanent evolution through construction rationalization measures. This was the push for the introduction of pre-blended renders, which only required mixing in situ. In the late 1990s, manual processes were replaced by machine application (ZANELATTO, 2012). According to Paravisi (2008), the use of mechanical shotcrete systems may contribute to increasing the degree of rationalization of rendering subsystems, reducing the dependence on operator skill and the associated variability in production.

According to Nakakura and Vieira (2015), the following production systems used in shotcrete mixing and pumping operations can be identified:

(a) mixer-pumps for pre-blended mortars;

(b) dry-process shotcrete mixer pumps; and

(c) wet-process shotcrete mixer pumps.

In wet-process systems, the different constituents of the mortar (i.e. cement, aggregate, admixtures and water) are first batched and mixed together. They are then fed into the mixer-pump and the resulting mix is conveyed to the nozzle using compressed air. The operator can then spray the mix into place. In dry-process shotcrete systems, the dry constituents are mixed together and then conveyed under pressure through the delivery hose to the nozzle, where water under pressure is introduced to project the resulting mortar into place (AUSTIN; ROBINS; GOODIER, 1999).

Different types of mixes are used in mortar processing in the field. As regards to the shear rate applied to the mix to reduce clogging, Williams, Saal and Jennings (1999) concluded that higher shear rates in the paste result in improved deagglomeration and lower viscosity and thus facilitate flow. Yang and Jennings (1994) carried out a similar rheology study and found that low mixing energies cause stress peaks to increase and occur earlier. As a result, the products can be processed under a wide mixing efficiency range, because each of the shotcrete systems generates specific energy levels (CARDOSO, 2009). It should be remembered that each system uses specific mixing periods, different hose length and contact with the water (time of mixture), and other distinctive features.

It can be said that the adoption of a construction method that uses new rendering technologies is far from simple. Several peculiarities result in a more complex system by means of different degrees of industrialization. According to Santos (2003), the observation of construction sites practices shows that the process is conducted on a fully empirical basis and from a technological point of view, particularly with reference to the rheology and flow of these materials. Such a scenario perfectly justifies this study, which aims to improve our understanding of the influence of different shotcrete systems, with specific configuration and mixing energies, on the properties of fresh and hardened rendering mortars.

\section{Methods and materials}

\section{Planning step}

The planning step is of great importance to the success of the experiment as this is the moment when the response variables and the controlling factors in the study are defined.

The constant factors, i.e. those that were not chosen as priorities in this study, were the water inflow rate (set as $450 \mathrm{l} / \mathrm{h}$, as indicated in the device rotameter) and a mortar manufacturer (labelled A1). The response (dependent) variables investigated correspond to the property characterization assays 
in the fresh and hardened mortar. After the variables were defined, an experimental matrix was prepared, as shown in Figure 1, which shows possible combinations.

The material (mortar) was collected "in situ" and transported to the LAMTAC facility of the university (Materials and Technology Laboratory of Build Environments of the Federal University of Rio Grande do Sul - UFRGS) with due attention to the requirement that the collection site (construction site) must be located within $12 \mathrm{~km}$ from the testing facility. All collections were made in the morning.

Mortar samples were collected directly from the nozzle in an 18-liter container. In addition, collection took place as operations were in progress, i.e. all the equipment was adjusted to the flow set in the rotameter. Finally, the container was sealed with a lid before transport to minimize water loss in the mortar.

It should be highlighted that the results of the two shotcrete systems (E1and E2) will be compared to those of the reference mortar (labelled LabA1), which was prepared in a test mixer at LAMTAC, prepared as specified by Brazilian Standard NBR 13276 (ABNT, 2005a).

Before tests were started, fresh mortar was mixed by hand for 30 seconds with an iron rod to ensure the homogeneity of the material to be tested. In addition, in order to standardize test conditions and minimize the interference of any experimental noise, all characterization tests (E1, E2 e LabA1) started within an interval of 50 minutes. This interval was adopted to take account of the time needed to transport the samples after collection in the construction site to the laboratory.

\section{Shotcrete systems}

The controlled or independent variables are those parameters that influence the response variable. The controllable factor involves two different shotcrete systems: a dry-mix system (labeled E1) and a wetmix system (labeled E2) as shown in Figures 2 and 3 , respectively.

E1 consists of a dry pneumatic transport system (Figure 2b), which pneumatically transports the premixed dry products that are fed into the system from the ground level to the floor where the equipment is located (Figure 2a). The system feds the system in a closed circuit through the hoses (Figure 2c). When the gun is activated, water is inserted into the system (Figure 2d) only on the floor where the unit is located.

The E2 unit, as Figure 3 shows, consists of an integrated mixer and pump assembly and is called a stationary wet-mix mixing unit. The device is placed away from the projection turret. Water is mixed in the unit and the mixed is propelled through the hose to the rocker arm.

Figure 1 - Experimental matrix adopted in the study

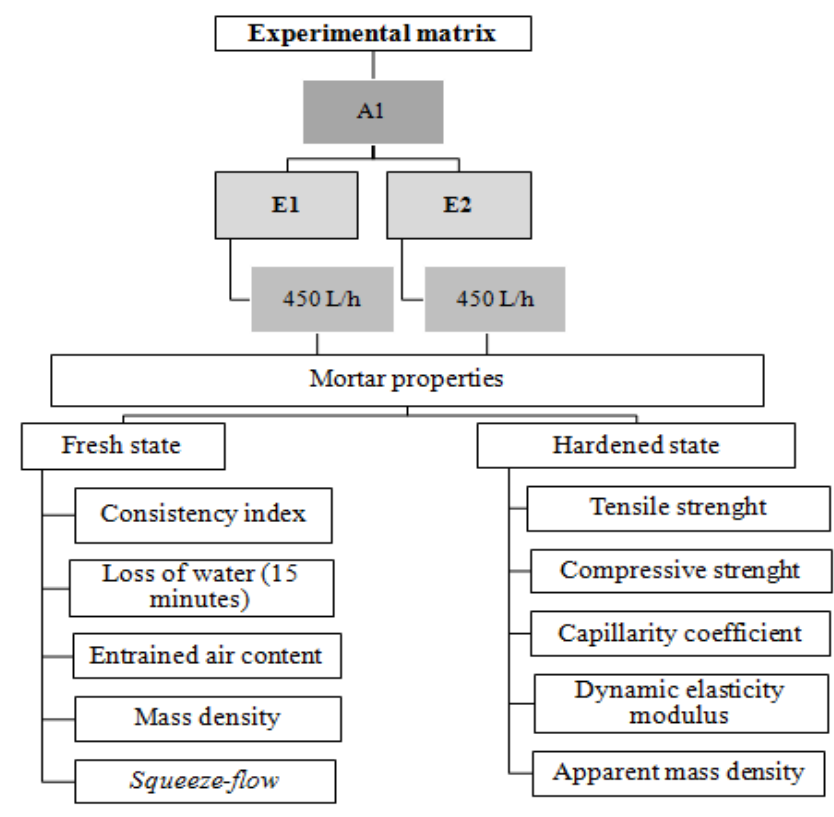


Figure 2 - Dry-mix shotcrete system (E1) - (a) place for mortar insertion; (b) dry transport system for mortar; (c) hoses that transport the mortar to the shotcrete unit; and (d) shotcrete unit (mixer and pump)

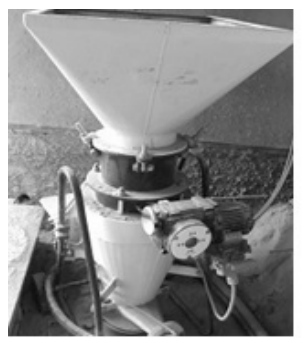

(a)

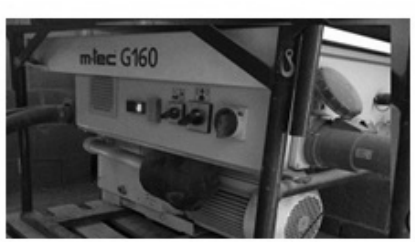

(b)

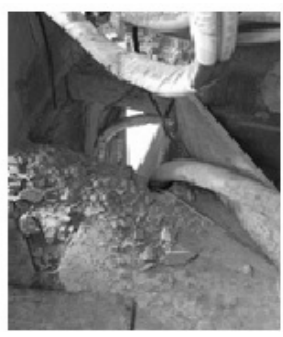

(c)

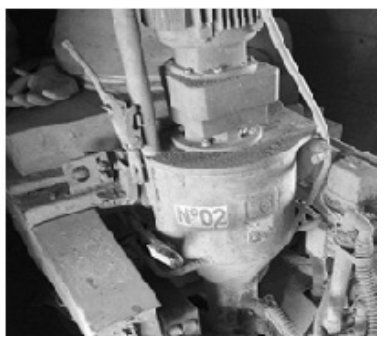

(d)

Figure 3 -Wet-mix shotcrete system (E2)

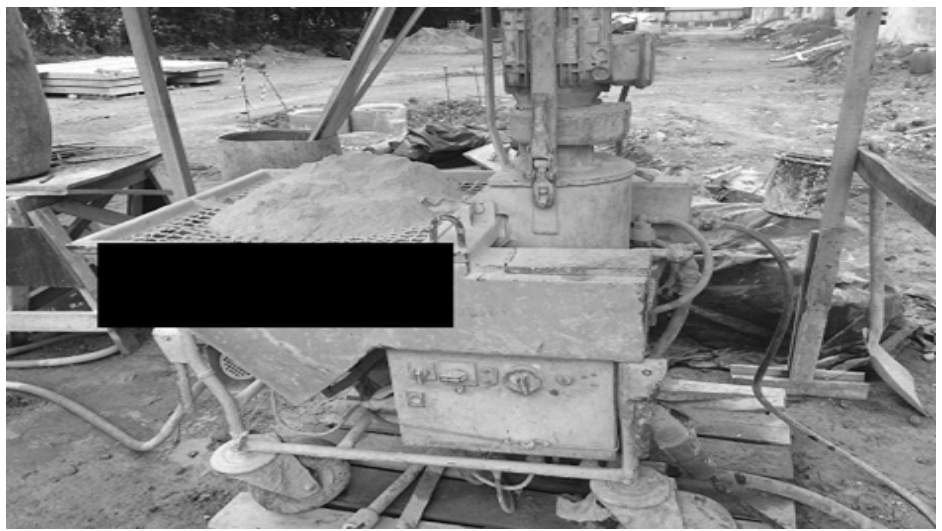

The systems were found in the same construction site and displayed some differences such as hose length, mixing energy and time and sequence of mixing with water.

\section{Mortar preparation}

The premix mortar, supplied by manufacturer 1 (A1) consists of a homogeneous mix of Portland cement, mineral aggregates of specific particle size and chemical admixtures. The mortar can be mixed by hand or in a mixer, which could be: continuous mixer (water flow is adjusted to match device throughput $-\mathrm{l} / \mathrm{h}$ - and the water amount per mix bag) and batch mixer. In this study, E1 and E2 were prepared in a continuous mixer and the reference mortar (LabA1) was prepared in a batch mixer.

\section{Characterization tests}

For the control of the mortars, test specimens measuring $4 \times 4 \times 16 \mathrm{~cm}$ were prepared as specified by Brazilian Standard NBR 13279 (ABNT, 2005b).

The test specimens were cured under controlled conditions at a temperature of $23 \pm 2^{\circ} \mathrm{C}$ and relative humidity of $60 \pm 5 \%$ and were so stored until testing. Mechanical testing was conducted in an EMIC press $($ maximum load $=2000 \mathrm{kN}$ ) and preparation and testing according to applicable standards, as shown in Figure 4, which summarizes the tests used to assess the fresh and hardened mortars, as well as the number of tests and test specimens prepared for testing.

The tests in fresh mortar were conducted according to the standards listed. However, as it was explained above, the tests started at 50 minutes and consistency was also tested at 100 minutes. In addition, water retention and squeeze-flow tests also required adaptations.

The water retention test method in rendering mortarsis specified by Brazilian standard NBR 13277 (ABNT, 2005c). In order to determine retention (\%), the water/fresh mortar ratio has to be known. However, it is not possible to determine this value because the actual mass of water added to the mix is not known. This would only be possible if the equipment was switched on and adjusted just to collect a sample. This would, however, yield unreliable results because the initial water content of fresh mortar is higher. Therefore, to characterize the mortar, the difference between the mass of the set, pan and fresh mortar before and after suction with a vacuum pump for 15 minutes was calculated and this was labeled "lost water content (15 minutes)”. 
Figure 4 - Characterization tests of the mortars

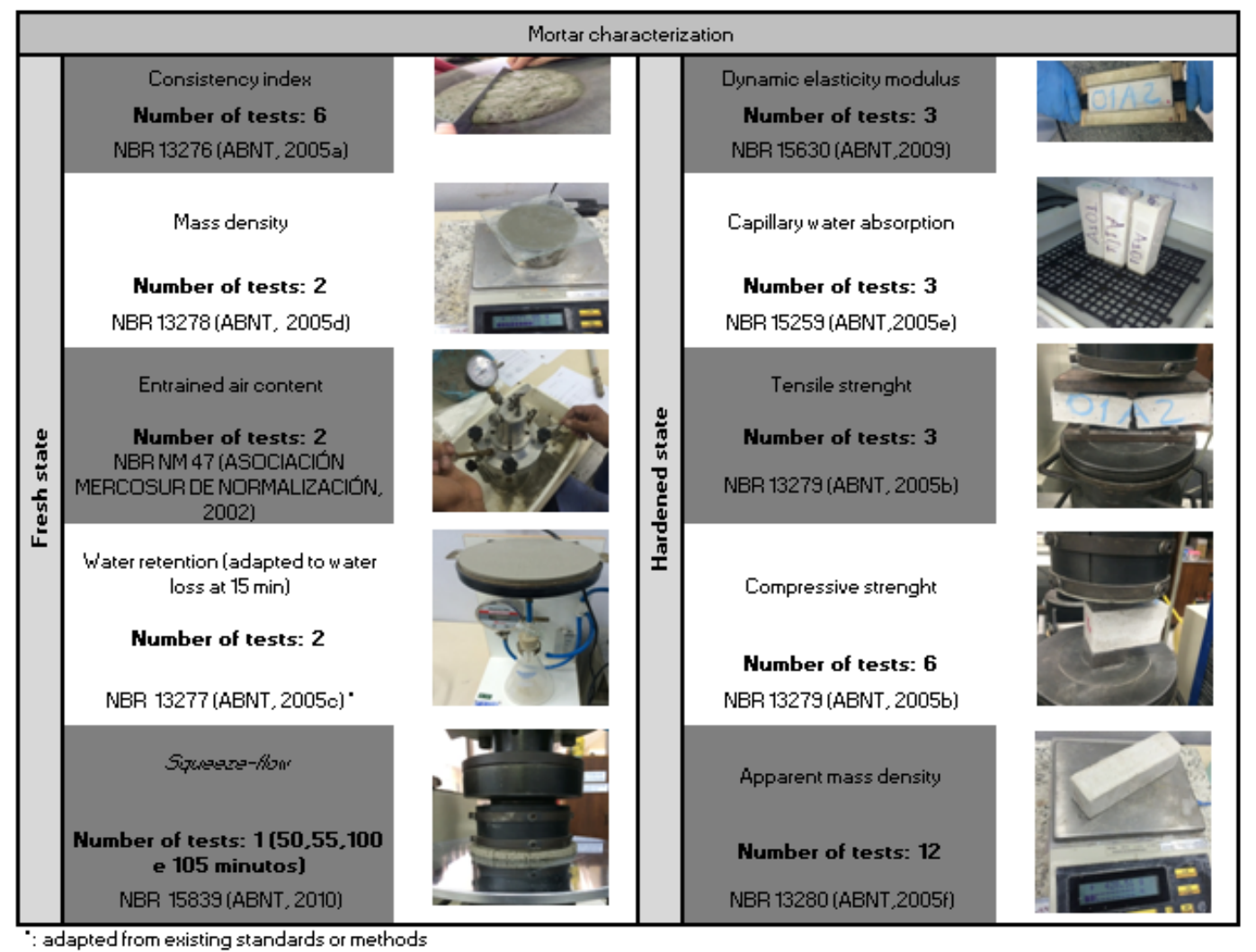

The squeeze-flow test provides an efficient alternative for the analysis of the rheology of cementitious materials (ANTUNES; JOHN; PILEGGI,2005) and was used to complement the consistency index test. The test follows Brazilian Standard NBR 15839 (ABNT, 2010) and is used to determine the rheological behavior of fresh rendering mortars under compression. This standard prescribes that the time elapsed between the end of the mortar preparation and the effective beginning of the test should be 10 minutes and 60 minutes for a speed of $3 \mathrm{~mm} / \mathrm{s}$ and 15 and 65 minutes for a speed of $0.1 \mathrm{~mm} / \mathrm{s}$. Because of the time required for collection and transportation, the beginning of the test happened effectively 50 and 100 minutes after collection for the speed of $3 \mathrm{~mm} / \mathrm{s}$ and 55 and 105 minutes for the speed of $0.1 \mathrm{~mm} / \mathrm{s}$.

\section{Presentation and discussion of results}

Analysis of variance (ANOVA) with a 95\% confidence interval was used to examine the effect of production systems on the properties of fresh and hardened mortar (the software package used was
Statistica 8). All results are presented alongside the reference values for the pre-blended mortar, which was prepared according to the manufacturer's instructions for batching and mixing (sample LabA1, prepared in the laboratory).

Appendices A and B list the results, mean values, coefficient of variation (CV\%) and standard deviation (SD) for each of the characterization tests of the fresh mortars in the study. Appendix A shows consistency index andmass density, while Appendix B shows entrained air and water retention (loss of water) results.

Appendices $\mathrm{C}$ and $\mathrm{D}$ show the results, means, coefficient of variation (CV\%) and standard deviation (SD) values for each of the characterizations tests of hardened mortar samples. C lists elasticity module and capillarity coefficient results while Appendix D lists mechanical strength and apparent mass density.

Table 1 summarizes results for the multiple analysis of the means using Fisher's method and indicates the variable with significant differences, as shown in key of Figure 5. 
Table 1 - Summary of mortar characterization tests using Fisher's method for multiple analysis of the means

\begin{tabular}{|c|c|c|c|c|c|}
\hline \multicolumn{6}{|c|}{ Mortar characterization } \\
\hline \multicolumn{6}{|c|}{ A1 } \\
\hline \multirow{2}{*}{\multicolumn{3}{|c|}{$\begin{array}{l}\text { E1/E2: comparison between E1 and E2 mortars } \\
\text { E1/Ref.: comparison between E1 and reference (lab) mortars } \\
\text { E1/Ref.: comparison between E2 and reference (lab) mortars }\end{array}$}} & \multicolumn{3}{|c|}{ Influence of system } \\
\hline & & & E1/E2 & E1/Ref. & E2/Ref. \\
\hline \multirow{5}{*}{ 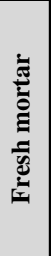 } & \multirow{2}{*}{ Consistency index } & at $50 \mathrm{~min}$ & & & \\
\hline & & at $100 \mathrm{~min}$ & & & \\
\hline & \multicolumn{2}{|c|}{ Massa density } & & & \\
\hline & \multicolumn{2}{|c|}{ Entrained air content } & & & \\
\hline & \multicolumn{2}{|c|}{ Water retention (adapted to loss of water at $15 \mathrm{~min}$ ) } & & & \\
\hline \multirow{5}{*}{ 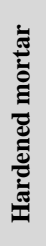 } & \multicolumn{2}{|c|}{ Dynamic elasticity modulus } & & & \\
\hline & \multicolumn{2}{|c|}{ Water absorption (capillarity coefficient) } & & & \\
\hline & \multicolumn{2}{|c|}{ Flexural strength } & & & \\
\hline & \multicolumn{2}{|c|}{ Compressive strength } & & & \\
\hline & \multicolumn{2}{|c|}{ Apparent mass density } & & & \\
\hline
\end{tabular}

Figure 5 - Key used in the summary table of the analysis (comparison between the two systems)

\begin{tabular}{|c|c|}
\hline \multicolumn{1}{|c|}{ KEY: } \\
\hline & Results show a significant difference \\
\hline & Results do not show a significant difference \\
\hline
\end{tabular}

The next section presents an analysis of the properties and other required observations, as well as an analysis of squeeze-flow test results. The horizontal bar in the graphs below represents indicates that there was no statistically significant difference in the results of different shotcrete equipment types.

In the consistency index test, it can be observed that for a given flow rate, equipment 1 (E1) yields a higher mean value when compared with equipment 2 (E2), as Figure 6 shows. It should be noted that the mean result for the reference mortar (LabA1) is higher for both times (50 and 100 minutes).

Results show that mortars E1 e E2 mixed in situ have a lower flow table index when compared with the reference mortar (LabA1).

At 100 minutes, regardless of the equipment used, mortars show similarities and display the smallest difference between results. All mortars collected and produced, in the case of the reference mortar (LabA1), show a reduction in this index at 100 minutes, unlike the mortar collected in equipment 2 (E2), which showed practically constant results.Figure 6 shows that there was no difference between the two shotcrete systems (E1 and E2) at
100 minutes when consistency index results are compared. At 50 minutes, however, it was found the type of shotcrete equipment affects this property (response variable).

For the squeeze-flow test, Figure 7 and Figure 8, mainly, show graphs with load changes associated with an uneven flow of the material. According to Cardoso, Pileggi and John (2005), some mortars (usually those of intermediate consistency levels) flow and then stop. When they stop flowing, load values increase and when the flow is resumed, the load then drops. This phenomenon is related to the friction between the plates and the mortar and also to the internal strain and flow mechanisms in the material. In Figure 8, with a lower displacement rate $(0.1 \mathrm{~mm} / \mathrm{s})$, the flow capacity dropped. This fact may be related to the repositioning of particles inside the mix, which blocks movement and causes the early onset of the strain-stiffening phase of the mortars because of the friction between the particles.

Figures 7 and 8 show that a reduction in the displacement rate reduces deformation. In addition, it was observed that for a displacement rate of 3 $\mathrm{mm} / \mathrm{s}$, phases I (elastic) and II (plastic) are clearly 
defined, showing small and intermediate displacement, respectively. For a rate of $0.1 \mathrm{~mm} / \mathrm{s}$, phase III (when the load increases because of the stiffening associated with grain deformation) is readily identifiable. The occurrence of phase III in this case may have been observed due to the fact that at low flow rates, the liquid has more time to flow radially when compared with situations when high flow rates are used. Therefore, phase separation tends to increase when the compressive speed is lower. This may produce the induction of the radial migration of the liquid through the structure formed by the particles and, therefore, an increase in the concentration of solids in the central section of the sample and in the force required to continue to compress the material. The same phenomenon was also observed by Cardoso et al. (2016).

At 50 and 100 minutes, with a rate of $3 \mathrm{~mm} / \mathrm{s}$, higher loads are required to induce deformation in the mortar collected from equipment 2 (E2) than for the reference mortar (LabA1) and equipment 1 mortar (E1). For a rate of $0.1 \mathrm{~mm} / \mathrm{s}$, at 55 and 105 minutes, it was observed that the mortar from equipment 2 (E2) reaches the maximum load in the test with lower displacement than what is observed in equipment 1 (E1).

Figure 6 - Influence of the mixing equipment on the consistency index (shotcrete equipment mortars and reference samples)

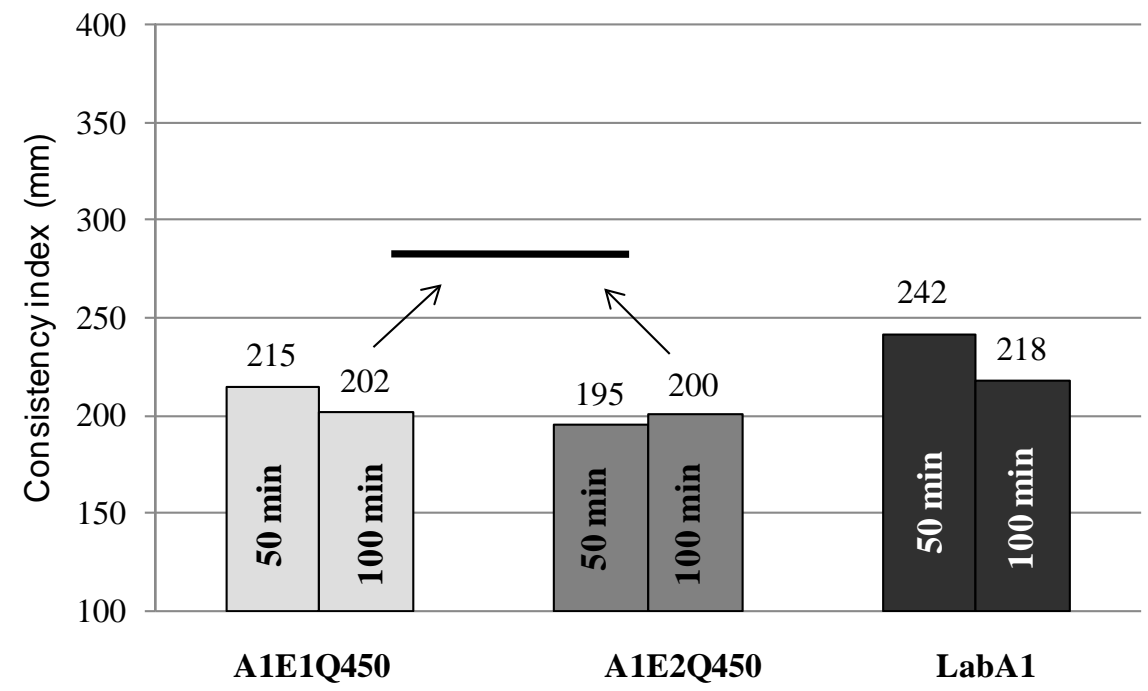

Figure 7 - Squeeze-flow and strainof different mortars with a displacement rate of $3 \mathrm{~mm} / \mathrm{s}$

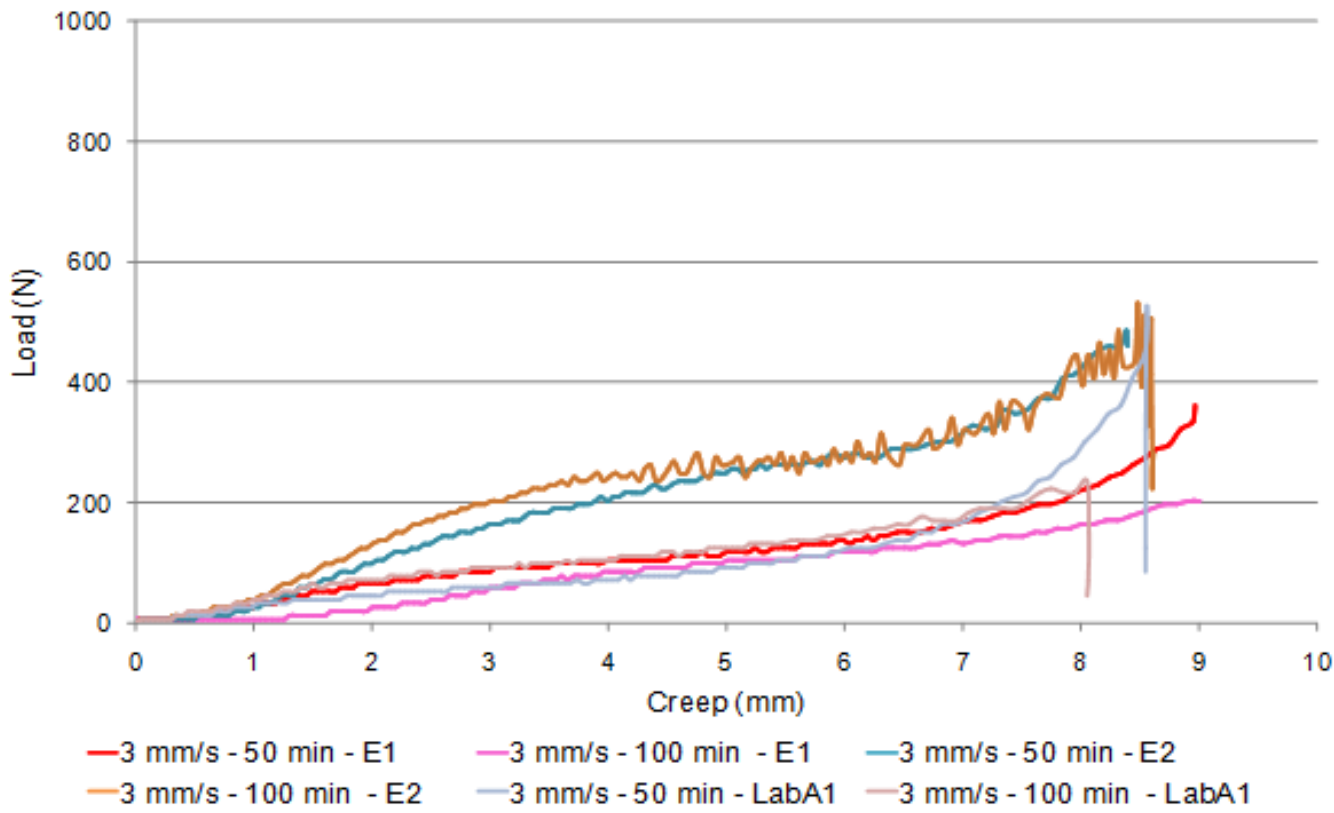


Figure 8 - Squeeze-flow and deformation of different mortars with a displacement rate of $0.1 \mathrm{~mm} / \mathrm{s}$

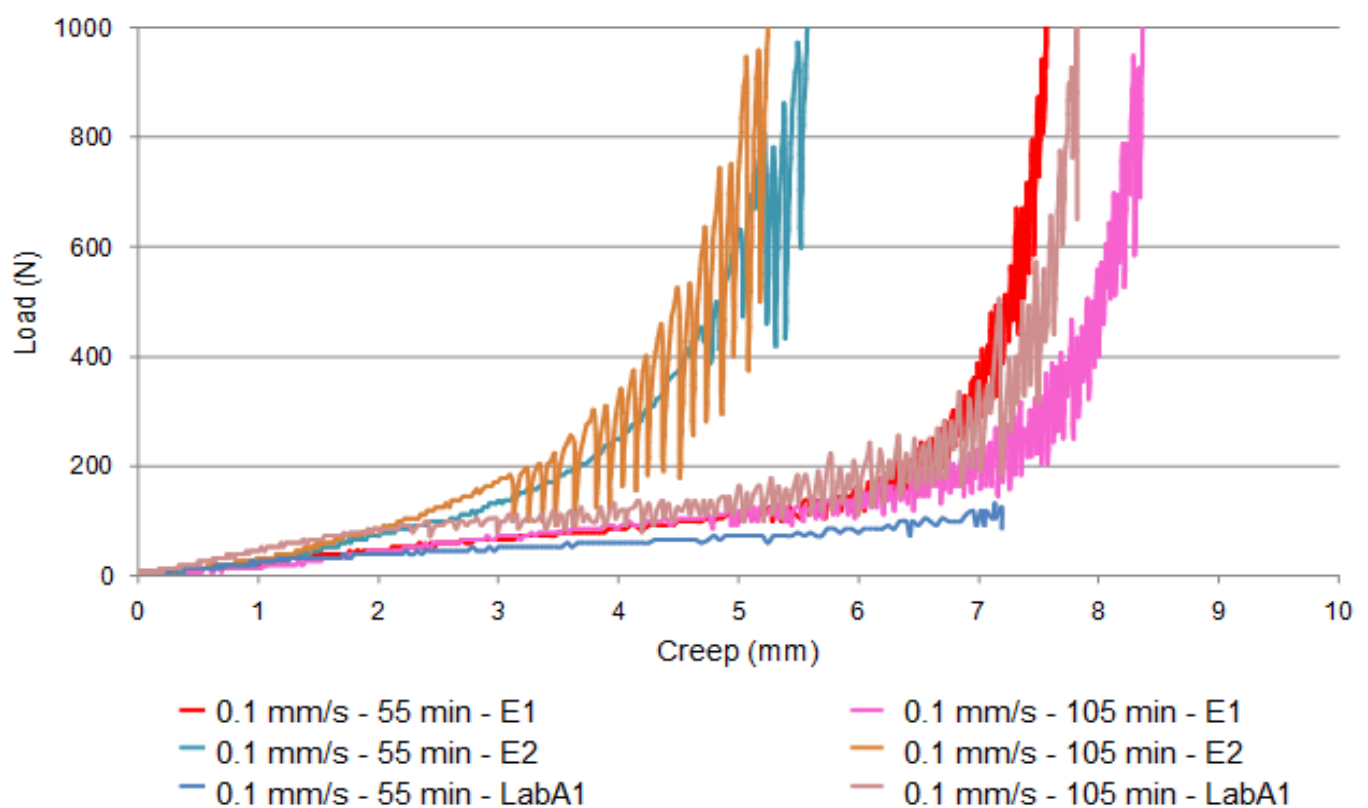

The different shotcrete units used in this test (E1 and E2) are based on different operation principles, which affect the type of contact between mortar and water, how long this contact takes place, as well as the mixing energies used. Antunes, John and Pileggi (2005) claim that the energy required for mixing, the amount of water and the mixing time are factors that greatly affect mortar properties. Pileggi et al. (2001) used a rotational viscometer for concrete to determine the amount of energy transferred to the system during mixing and showed that the process used to add water to refractory concrete produced significant changes in the process and the resulting rheological behavior. Barbosa (2010) tested two applications with different mixing energies and found that they resulted in specific rheological properties, which were also observed in other fresh state tests. This justifies the occurrence of a statistically significant difference in the consistency index and the distinctive behavior of the mortars in the squeeze-flow test, since these are rheological characterization tests.

It should be pointed out that there is coherence in relating the consistency index and the squeeze-flow, given that lower consistency index values are matched by higher resistance to flow, which means that higher loads are required to move the material. However, the statistically not significant result for the consistency index at 100 minutes between E1 and E2 is not observed in the squeeze-flow test. This is due to the fact that the tests in the consistency table is insufficient to assess the rheological nature of mortars, as it cannot isolate the contribution of flow stresses and the viscosity in the resistance to flow.
The fact that tests of the wet-process mortar (E2), in which the time of contact with water is longer, showed that higher loads are needed to obtain the same deformation observed in E1, which was produced with the dry-process system, may be related to the fact that this mortar needs rheological properties that prevent segregation, with increased resistance to flow and the possibility of clogging the hose.

The mass density of fresh mortar was also assessed, but the results did not show any statistical inference. In other words, the choice of shotcrete system did not affect this property. However, systems E1 and E2 show different results when compared to the reference mortar (LabA1).

With reference to the entrained air content, Figure 9 shows that even though no statistically significant difference between the systems was observed, entrained air content is higher in equipment 2 (E2) when compared with equipment 1 (E1). It was also observed that the reference mortar (LabA1) showed higher entrained air content when compared with the shotcrete systems.

Other studies of commercial mortars, such as those of Casali et al. (2001) and Romano et al. (2009), assessed entrained air content using different times and mixing energies and confirmed that the air content increases when longer mixing times are used. This was also observed in this study, as Figure 9 shows. The wet-mix mortar (E2) has a longer period of contact with water than E1. E2 also has a longer mixing time as a result of the pumping process, where by the wet pre-mixed material is transported by air pressure to simulate the 
continuity of the mixture. However, the fact that no statistically significant difference between the drymix and the wet-mix process was observed must be further investigated as this seems to contradict the findings of Nakakura e Cincotto (2001), who found in their study of the influence of time and type of mixing variations of up to $50 \%$ in entrained air content. In this study, as can be seen in Table 2, high coefficients of variation were recorded, a fact which may explain the behavior of this property.

The modified water retention test offers some interesting insights, as Figure 10 shows. It can be seen that the loss of water is more significant in equipment 1 (E1) than equipment 2 (E2). A significant reduction was also observed in the mass of water lost in the reference mortar (LabA1).

Water retention is defined by Cincotto, Silva and Carasek (1995) as the capacity of fresh mortar to retain its consistencyor workability when subjected to stresses that result in dewatering. These authors claim that water retention, in addition to determining mortar handling conditions, also affects the properties of hardened mortar. When water is lost, this modifies the contact characteristics between mortar and substrate and affects drying shrinkage, mechanical and bond strength. Barbosa (2010) concluded in his study that different mixing energies result in different values of watersorptivity.

Figure 9 - Influence of shotcrete equipment in entrained air content (shotcrete equipment mortars and reference samples)

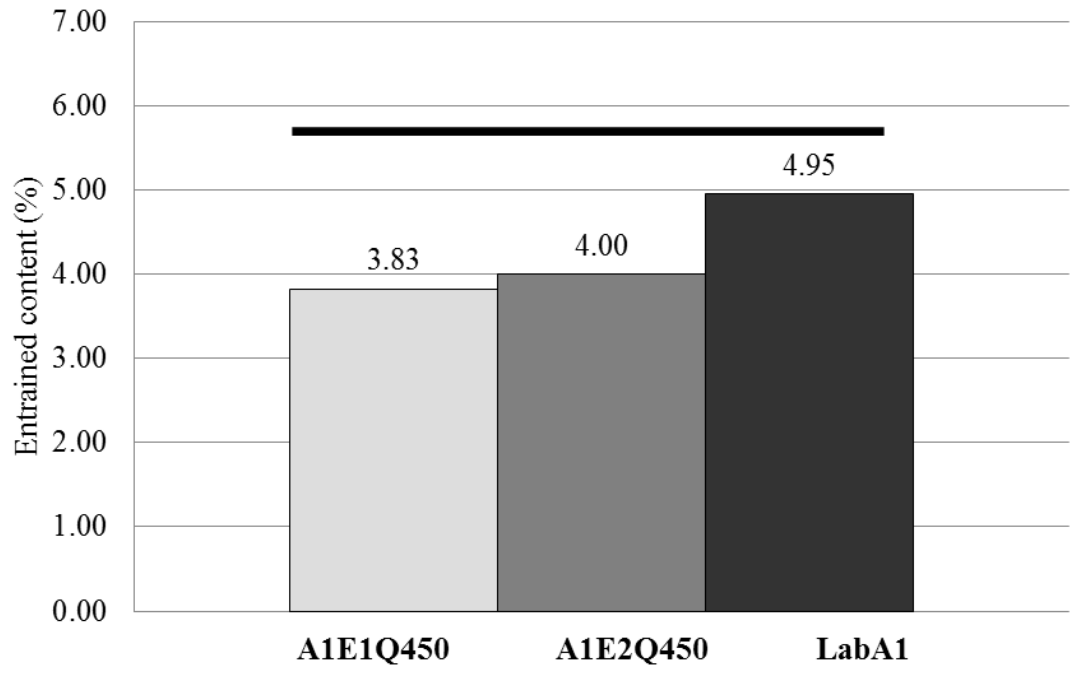

Figure 10 - Influence of the mixing equipment on the mass of water lost (shotcrete equipment mortars and reference samples)

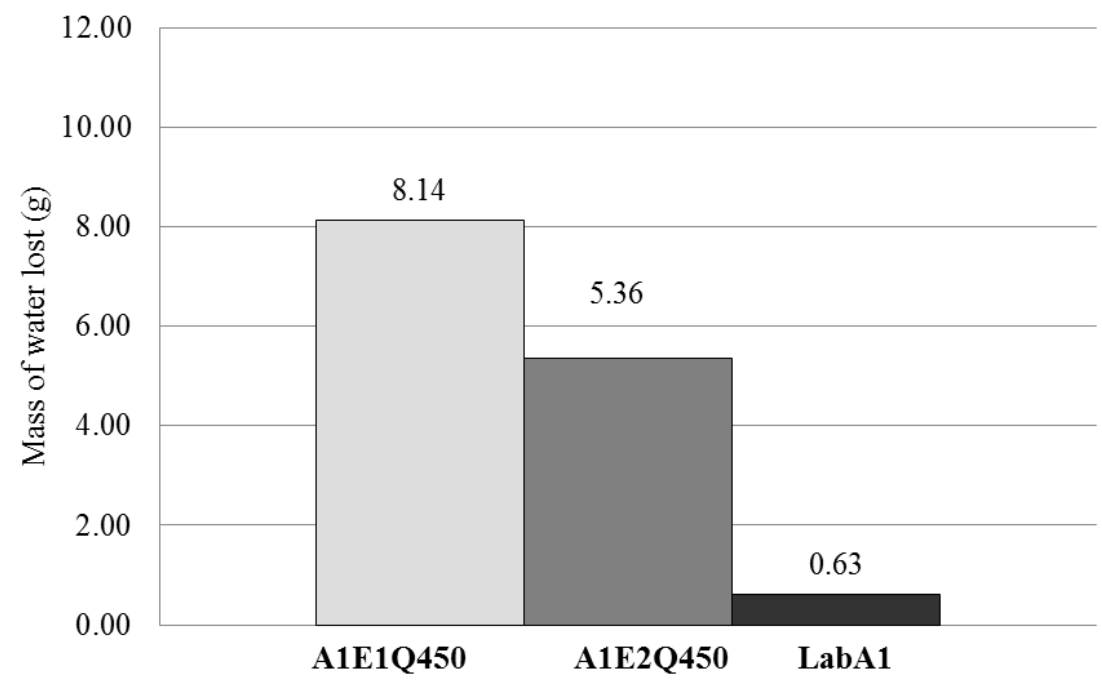


Do Ó (2004) claims that mortars with higher entrained air content are less consistent, i.e. more fluid (higher consistency index), which possibly results in more free water being present in the structure and a more intense loss of water, i.e. water retention is reduced, a behavior that was also reported by Stolz (2011). Our study, however, did not show the same behavior because the mortars with higher entrained air content showed the lowest loss of water and higher water retention capacity. This is probably due to the presence of unspecified additions in the mortar that are not informed by the manufacturer. Some additions, when combined with different mixing energies, can increase plasticity and reduce exudation, this directly affecting water retention. In addition, this analysis in the present study was compromised by the high coefficients of variation observed in the entrained air test. Still, the results found here corroborate the study of Moura (2007), who reported different findings than those of Do Ó (2004) and Stolz (2011). The air bubbles that result from the increased air content facilitates the sliding of the particles and improves plasticity and water retention. In other words, the loss of water (the mass of water loss, in grams) is lower.

For the hardened mortars, no statistical inference was observed in the dynamic elasticity modulus results. However, statistical inference was observed between the results of the capillarity coefficient (C), which measures the rate of capillary absorption that goes through the pore network of mortar as a function of the square root of time. The coefficient was calculated from the data generated by the water absorption test, which was conducted according to Brazilian Standard NBR 15259 (ABNT, 2005e). Figure 11 shows that the highest coefficient corresponds to E1 mortar (E1) and that the lowest coefficient is that of the reference mortar (LabA1). The capillarity coefficient is inversely proportional to the results of entrained air, as expected. It is likely that this is due to the presence of entrained air in the mortar, which reduces water absorption by capillarity as air bubbles block and/or hinder the flow in the capillaries.

Although no statistically significant difference was observed, as was the case with entrained air, this work confirms the findings of Casali et al. (2001) and Romano et al. (2009), who found that compressive strength is reduced when entrained air values and mixing times increase. Figure 12 shows that the mean result of E2 mortar is lower than for E1 mortar.

According to Mattana et al. (2012), higher entrained air contents result in better workability and lower mechanical strength. This can be seen in Figures 12 and 13 of this study, which show that a higher entrained air content (in sample E2) was matched by lower compressive and flexural strength values. In addition, Table 4 shows high coefficient of variation values, which may have affected statistical analysis and therefore no difference was observed in the result of the test.

Figure 11 - Influence of mixing equipment type on capillarity coefficient (shotcrete equipment mortars and reference samples)

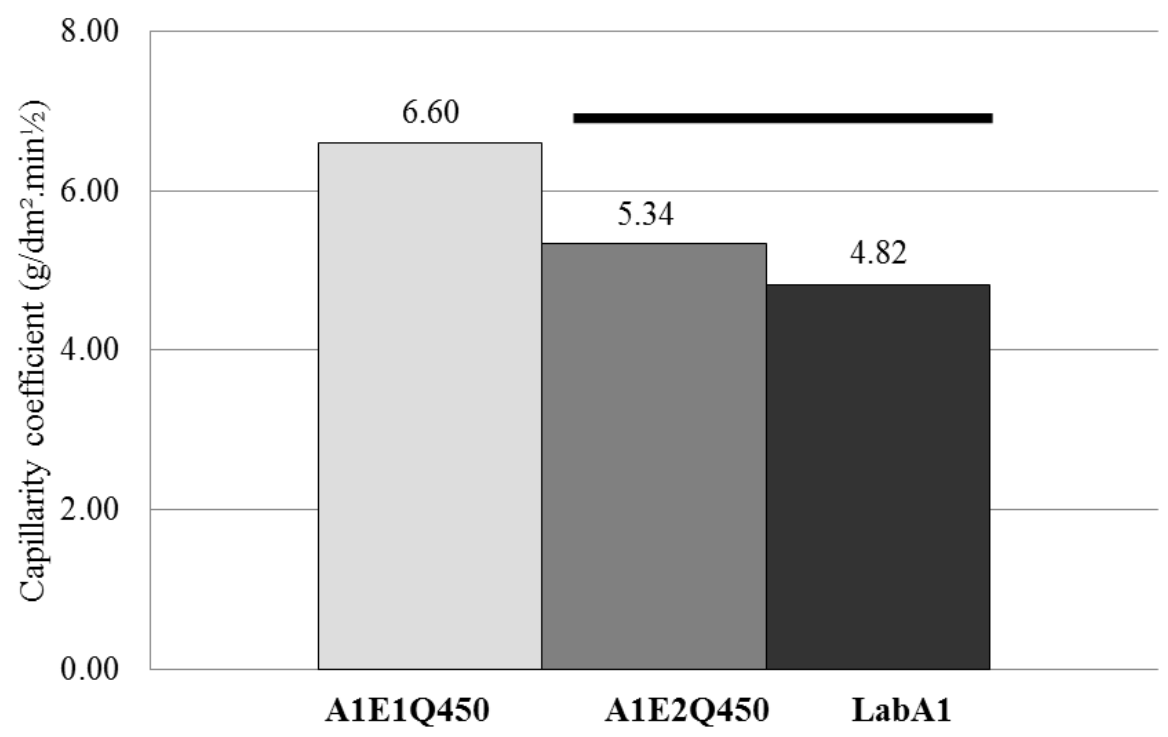


Figure 12 - Influence of mixing equipment on compressive strength (shotcrete equipment mortars and reference samples)

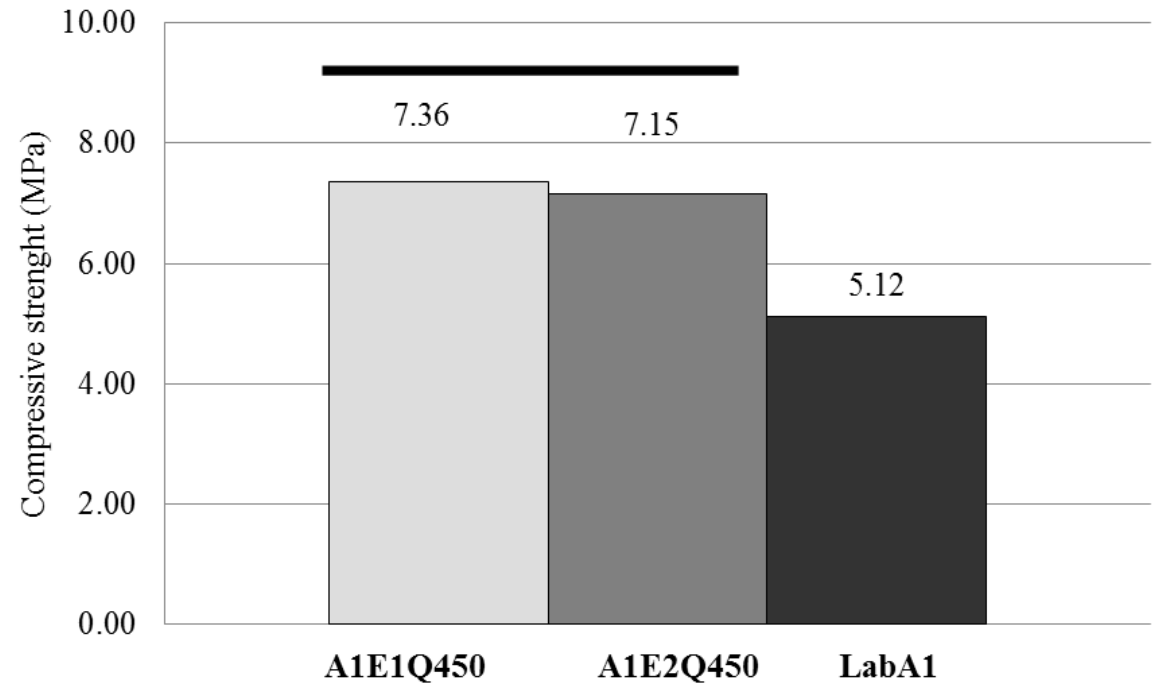

Figure 13 - Influence of mixing equipment on flexural strength (shotcrete equipment mortars and reference samples)

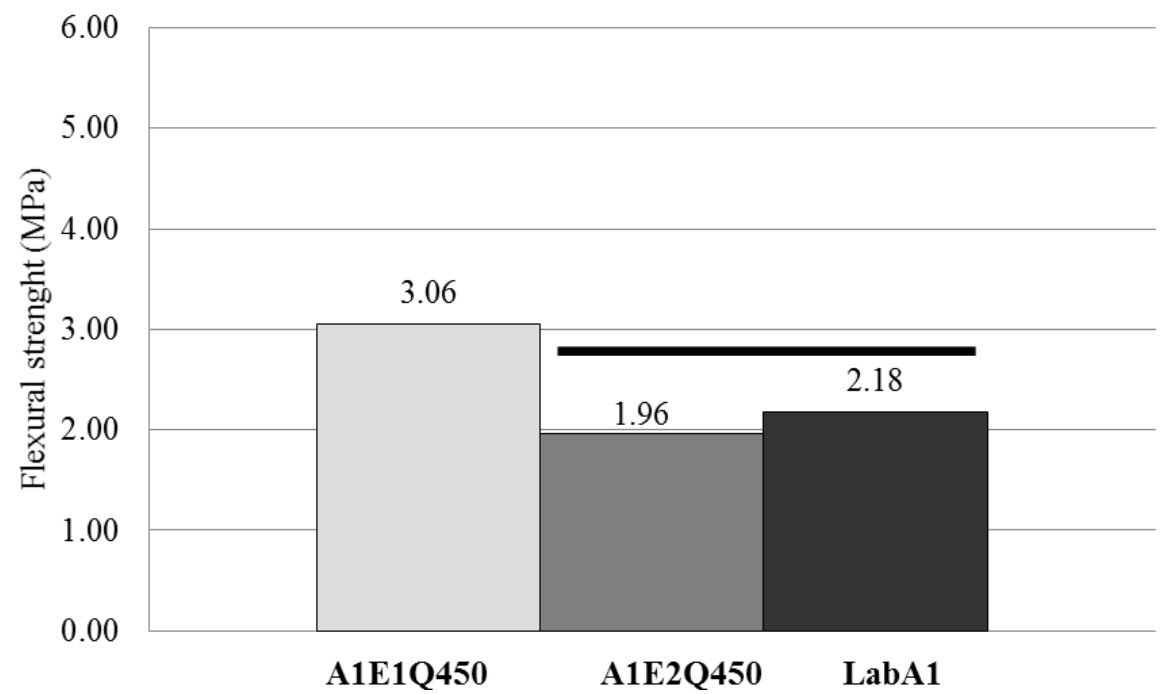

Compressive strength is more often a concern for laying mortar applications, because of the forces that may affect the sealing system. On the other hand, for rendering mortars, the most important forces are flexural strength and shear strength because the mortar must withstand stress-strain forces and no cracking should form (NAKAKURA; CINCOTTO, 2004). E1 and E2 displayed a statistically significant difference in the tensile strength test. The wet E2 system, in which the mortar has a longer contact time with water, showed a reduction in tensile strength, a behavior that was also reported by Romano et al. (2009). Mattana et al. (2012) consider that the higher the content of incorporated air, the better the workability and the lower the mechanical resistance. This fact can be verified, in the present work, through Figure 9,

Figure 12 and Figure 13. Alves (2002) suggests that this behavior can be related to the presence of larger air bubbles that reduce mechanical resistance.

Finally, the apparent density of the hardened mortar,which is associated with the entrained air content in the fresh mortar, in the same way as in this study, did not show statistical inference between the results. However, a statistically significant difference was observed between systems E1 and E2 when compared to the reference mortar (LabA1). 


\section{Final considerations}

The use of shotcrete systems to replace conventional manual labor has several advantages, such as less interference associate with the operator skill, better homogeneity in mixing and spraying, improved quality and performance of the mortar and render, etc. However, this study showed that the type of shotcrete system used may affect results. More specifically, the mixing stage shows statistical inference on the consistency index and water retention (loss of water at 15 minutes) of fresh mortar. For hardened mortar, statistical inference was observed for the flexural strength and the capillarity coefficient in dry- and wet-mix equipment.

The mean analysis of the means shows that the mortar produced in equipment 2 (E2) is more similar to the reference mortar (LabA1) produced in the laboratory.

Consistency/flow-table/slump and squeeze-flow tests showed that different shotcrete systems result in different mortar behaviors.

The mortar produced using a wet-mix system (E2) resulted in lower loss of water, with flexural strength approximately 35\% lower than the mortar in the dry-mix system (E1). For compressive strength, no significant difference was found for the two systems, but this was not the case for the capillarity coefficient, which was higher in E2 mortars. This behavior is probably associated with the connectivity of the mortar pore network. The results for most properties assessed in this study show statistical inference when the dry- and wetmix shotcrete mortars are compared with the reference mortar produced in the laboratory. In other words, the resulting mortars display distinctive behaviors. This is a result of the different mixing times, mixing energy and the way water is introduced into the system.

The results show that mortar properties can display variations that may affect the performance of the render. It is therefore important to determine whether the mortar that will be used is compatible with a specific shotcrete system and so make full use of the potential of mechanized systems.

\section{References}

ALVES, N. J. D. Avaliação dos Aditivos Incorporadores de Ar em Argamassa de Revestimento. Brasília, 2002. 174 f. Dissertação (Mestrado em Engenharia Civil) - Departamento de Engenharia Civil e Ambiental, Universidade de Brasília, Brasília, 2002.
ANTUNES, R. P. N.; JOHN, V. M.; PILEGGI, R. G. Influência da seqüência de mistura nas propriedades reológicas de argamassas avaliada por squeeze-flow. In: SIMPÓSIO BRASILEIRO DE TECNOLOGIA DE ARGAMASSAs, 6., Florianópolis, 2005. Anais... Florianópolis: ANTAC, 2005.

ASOCIACIÓN MERCOSUR DE NORMALIZACIÓN. NM 47: determinação do teor de ar em concreto fresco: método pressiométrico. São Paulo, 2002.

\section{ASSOCIAÇÃO BRASILEIRA DE NORMAS}

TÉCNICAS. NBR 13276: argamassa para assentamento de paredes e tetos: preparo da mistura e determinação do índice de consistência. Rio de Janeiro, 2005a.

\section{ASSOCIAÇÃO BRASILEIRA DE NORMAS} TÉCNICAS. NBR 13278: argamassa paraassentamento e revestimento de paredes e tetos: determinação da densidade de massa e do teor de ar incorporado. Rio de Janeiro, 2005d.

\section{ASSOCIAÇÃO BRASILEIRA DE NORMAS} TÉCNICAS. NBR 13279: argamassa paraassentamento e revestimento de paredes e tetos: determinação da resistência à tração na flexão e à compressão. Rio de Janeiro, 2005b.

\section{ASSOCIAÇÃO BRASILEIRA DE NORMAS} TÉCNICAS. NBR 13280: argamassa paraassentamento e revestimento de paredes e tetos: determinação da densidade de massa aparente no estado endurecido. Rio de Janeiro, $2005 f$.

\section{ASSOCIAÇÃO BRASILEIRA DE NORMAS} TÉCNICAS. NBR 15259: argamassa para assentamento e revestimento de paredes e tetos: determinação da absorção de água por capilaridade e do coeficiente de capilaridade. Rio de Janeiro, 2005e.

\section{ASSOCIAÇÃO BRASILEIRA DE NORMAS TÉCNICAS. NBR 15630: argamassa para assentamento e revestimento de paredes e tetos: determinação do módulo de elasticidade dinâmicoatravés da propagação de onda ultrassônica. Rio de Janeiro, 2009.}

\section{ASSOCIAÇÃO BRASILEIRA DE NORMAS TÉCNICAS. NBR 15839: argamassa para assentamento e revestimento de paredes e tetos: caracterização reológica pelo método squeeze- flow. Rio de Janeiro, 2010.}

\section{ASSOCIAÇÃO BRASILEIRA DE NORMAS} TÉCNICAS. NBR13277: argamassa para assentamento e revestimento de paredes e tetos: determinação da retenção de água. Rio de Janeiro, 2005c. 
AUSTIN, S. A.; ROBINS, P. J.; GOODIER, C. I. The Reological Performance of Wet-Process Sprayed Mortars. Magazine of Concrete Research, v. 51, n. 5, p. 341-352, 1999.

BAÍA, L. L. M.; SABBATINI, F. H. Projeto e Execução de Revestimento de Argamassa. São Paulo: O Nome da Rosa, 2000. (Coleção Primeiros Passos da Qualidade no Canteiro de Obras).

BARBOSA, W da S. Alteração do Comportamento Reológico da Suspensão Cimentícia Aplicada Sobre Substratos Porosos. São Paulo, 2010. 152 f. Thesis (Master’s dissertation) - Escola Politécnica, Universidade de São Paulo, São Paulo, 2010.

BRITEZ, A.A. Diretrizes Para Especificação de Pinturas Externas Texturizadas Acrílicas em Substratos de Argamassa. São Paulo, 2007. 148 f. Theis (Master's dissertation) - Escola Politécnica, Universidade de São Paulo, São Paulo, 2007.

CARDOSO, F.A et al. Caracterização de Pasta de Cimento Por Reometria de Placas Paralelas.In: CONGRESSO BRASILEIRO DE CERÂMICA, 60., Águas de Lindóia, 2016. Anais... Águas de Lindóia, 2016.

CARDOSO, F.A. Método de Formulação de Argamassas de Revestimento Baseado em Distribuição Granulométrica e Comportamento Reológico. São Paulo, 2009. 158 f. Doctoral thesis - Escola Politécnica, Universidade de São Paulo, São Paulo, 2009.

CARDOSO, F.A.; PILEGGI, R.G.; JOHN, V.M. Caracterização Reológica de Argamassas Através do Método de Squeeze-Flow. In: SIMPÓSIO BRASILEIRO DE TECNOLOGIA DE ARGAMASSAS, 6., Florianópolis, 2005. Anais... Florianópolis: ANTAC, 2005.

CARNEIRO, A. M. P. Revestimento Externo em Argamassa de Cimento, Cal e Areia: sistemática das empresas de construção civil de Porto Alegre. Porto Alegre, 1993. 136 f. Civil Engineering Graduate Program, Universidade Federal do Rio Grande do Sul,Porto Alegre, 1993.

CASALI, J. M. et al. Avaliação da Influência do Processo de Mistura na Resistência à Compressão de Argamassas Para Assentamento de Alvenaria Estrutural. In: SIMPÓSIO BRASILEIRO DE TECNOLOGIA DAS ARGAMASSAS, 4., Brasília, 2001. Anais... Brasília: ANTAC, 2001.

CINCOTTO, M. A.; SILVA, M. A. C.; CARASEK, H. Argamassas de Revestimento: características, propriedades e método de ensaio. São Paulo: Instituto de PesquisasTecnológicas. 1995. (Boletim 68).
COSTA, F. N. Processo de Produção de Revestimento de Fachada de Argamassa: problemas e oportunidades de melhoria. Porto Alegre, 2005. Thesis (Master's dissertation) Civil Engineering Graduate Program, Universidade Federal do Rio Grande do Sul, Porto Alegre, 2005.

DO Ó, S. W. Análise da Retenção de Água em Argamassas de Revestimento Aditivadas. Brasília, 2004. 173 f. Dissertação (Mestrado em Engenharia Civil) - Escola de Engenharia, Universidade de Brasília, Brasília, 2004.

MASSETTO, L. T. et al. Novas Tecnologias de Produção de Revestimentos Verticais de Argamassa: organização da produção e produtividade. In: ENCONTRO NACIONAL DE TECNOLOGIA DO AMBIENTE CONSTRUÍDO, Florianópolis, 1998. Proceedings... Florianópolis, 1998.

MATTANA, A. J. et al.Análise Hierárquica Para Escolha Entre Agregado Natural e Areia de Britagem de Rocha Para Confecção de Argamassas de Revestimentos. Ambiente Construído, Porto Alegre, v.12, n.4, p. 63-79, out./dez. 2012.

MOURA, C. B. Aderência de Revestimentos Externos de Argamassa em Substratos de Concreto: influência das condições de temperatura e ventilação na cura do chapisco. Porto Alegre, 2007. 234 f. Dissertação (Mestrado em Engenharia Civil) - Programa de Pós-Graduação em Engenharia Civil, Universidade Federal do Rio Grande do Sul, Porto Alegre, 2007.

NAKAKURA, E. H.; CINCOTTO, M. A. Análise dos Requisitos de Classificação de Argamassas de Assentamento e Revestimento. São Paulo. São Paulo, 2004. Boletim Técnico da Escola Politécnica da USP.

NAKAKURA, E. H.; CINCOTTO, M. A. Revisão de Norma NBR 13581 Como Instrumento Para Melhor Representar o Desempenho de Argamassas Industrializadas em Obra. In: SIMPÓSIO BRASILEIRO DE TECNOLOGIA DAS ARGAMASSAS, 4., Brasília, 2001. Anais.. Brasília: PECC/ANTAC, 2001.

NAKAKURA, E.; VIEIRA, G. Ferramenta de Viabilidade (App). São Paulo: Pocket Book, 2015.

PARAVISI, S. Avaliação de Sistemas de Produção de Revestimentos de Fachada Com Aplicação Mecânica e Manual de Argamassa. Porto Alegre, 2008. Theis (Master's Dissertation) - Civil Engineering Graduate Program, Universidade Federal do Rio Grande do Sul, Porto Alegre, 2008. 
PILEGGI, R. G. et al. How mixing affects the rheology of refractory castables: parts I and II. American Ceramic Society Bulletin, v. 80, n. 6, p. 2731, p. 38-42, 2001.

ROMANO, R. C. O. et al. Sensibilidade de Argamassas de Revestimento ao Procedimento de Mistura. In: SIMPÓSIO BRASILEIRO DE TECNOLOGIA DAS ARGAMASSAS, 8., Curitiba, 2009. Anais... Curitiba: ANTAC, 2009.

SANTOS, C. C. N. Critérios de Projetabilidade Para as Argamassas Industrializadas de Revestimento Utilizando Bomba de Argamassa Com Eixo Helicoidal. Brasília, 2003. 138 f.

Master's Dissertation (Civil Construction and Structures) - School of Civil Engineering, Universidade de Brasília, Brasília, 2003.

SELMO, S.M.S. Dosagem de Argamassa de Cimento Portland e Cal Para Revestimento Externo de Fachadas dos Edifícios. São Paulo, 1989. 227 f. Thesis (Master’sdissertation) - Escola Politécnica da Universidade de São Paulo, São Paulo, 1989.
STOLZ, C. M. Interação Entre Parâmetros Reológicos de Argamassas e a Rugosidade de Substratos na Aderência de Argamassas de Revestimento. Porto Alegre, 2011.162 f.

Dissertação (Mestrado em Engenharia civil) Escola de Engenharia, Universidade Federal do Rio Grande do Sul, Porto Alegre, 2011.

WILLIAMS, D. A.; SAAK, A. W.; JENNINGS, H. M. The Influence of Mixing on the Rheology of Fresh Cement Paste. Cement and Concrete Research, v. 29, p. 1491-96, 1999.

YANG, M.; JENNINGS, H.M. Influences of Mixing Methods on the Microstructure and Rheological Behavior of Cement Paste. Advanced Cement Based on the Materials, v. 2, p. 70-78, 1995.

ZANELATTO, K. C. Avaliação da Influência da Técnica de Execução no Comportamento dos Revestimentos de Argamassa Aplicados Com Projeção Mecânica Contínua. 122 f. São Paulo, 2012. Master's dissertation - Civil Engineering Escola Politécnica, Universidade de São Paulo, São Paulo, 2012.

Appendix A:Characterization tests (consistency index and mass density) of fresh mortar produced in different types of shotcrete equipment

\begin{tabular}{|c|c|c|c|c|c|c|c|}
\hline \multicolumn{8}{|c|}{ Response variables (fresh mortar) } \\
\hline Sample ID & $\begin{array}{l}\text { Time } \\
\text { (min) }\end{array}$ & $\begin{array}{l}\text { Consistency index } \\
\text { (mm) }\end{array}$ & $\begin{array}{l}\text { Mean } \\
(\mathrm{mm})\end{array}$ & $\begin{array}{c}\text { Mass density } \\
\left(\mathrm{kg} / \mathrm{m}^{3}\right)\end{array}$ & $\begin{array}{l}\text { Mean } \\
\left(\mathrm{kg} / \mathrm{m}^{3}\right)\end{array}$ & $\begin{array}{c}\mathrm{SD} \\
\left(\mathrm{kg} / \mathrm{m}^{3}\right)\end{array}$ & $\begin{array}{l}\text { CV } \\
(\%)\end{array}$ \\
\hline \multirow{6}{*}{ E1 } & 50 & 216 & \multirow{3}{*}{215} & 1899 & \multirow{3}{*}{1904} & \multirow{3}{*}{7} & \multirow{3}{*}{0.34} \\
\hline & 50 & 215 & & 1909 & & & \\
\hline & 50 & 214 & & & & & \\
\hline & 100 & 204 & \multirow{3}{*}{202} & & & & \\
\hline & 100 & 200 & & & & & \\
\hline & 100 & 203 & & & & & \\
\hline \multirow{6}{*}{$\mathbf{E 2}$} & 50 & 195 & \multirow{3}{*}{195} & 1909 & \multirow{3}{*}{1911} & \multirow{3}{*}{4} & \multirow{3}{*}{0.21} \\
\hline & 50 & 191 & & 1914 & & & \\
\hline & 50 & 200 & & & & & \\
\hline & 100 & 201 & \multirow{3}{*}{200} & & & & \\
\hline & 100 & 200 & & & & & \\
\hline & 100 & 200 & & & & & \\
\hline \multirow{6}{*}{ LabA1 } & 50 & 242 & \multirow{3}{*}{242} & 1752 & \multirow{3}{*}{1758} & \multirow{3}{*}{7} & \multirow{3}{*}{0.41} \\
\hline & 50 & 240 & & 1763 & & & \\
\hline & 50 & 243 & & & & & \\
\hline & 100 & 220 & \multirow{3}{*}{218} & & & & \\
\hline & 100 & 216 & & & & & \\
\hline & 100 & 218 & & & & & \\
\hline
\end{tabular}


Appendix B: Characterization tests (entrained air content and loss of water) of fresh mortar produced in different types of shotcrete equipment

\begin{tabular}{|c|c|c|c|c|c|c|c|c|}
\hline \multicolumn{9}{|c|}{ Response variables (fresh mortar) } \\
\hline Sample ID & $\begin{array}{c}\text { Entrained air } \\
\text { content (\%) }\end{array}$ & $\begin{array}{c}\text { Mean } \\
(\%)\end{array}$ & SD (\%) & CV (\%) & Loss of water (g) & $\begin{array}{c}\text { Mean } \\
(\mathrm{g})\end{array}$ & $\mathrm{SD}(\mathrm{g})$ & $\begin{array}{l}\text { CV } \\
(\%) \\
\end{array}$ \\
\hline \multirow[b]{2}{*}{ E1 } & 3.8 & \multirow[b]{2}{*}{3.83} & \multirow[b]{2}{*}{0.04} & \multirow[b]{2}{*}{0.92} & 8.08 & \multirow[b]{2}{*}{8.14} & \multirow[b]{2}{*}{0.08} & \multirow[b]{2}{*}{1.04} \\
\hline & 3.85 & & & & 8.2 & & & \\
\hline \multirow{2}{*}{ E2 } & 3.5 & \multirow{2}{*}{4.00} & \multirow{2}{*}{0.71} & \multirow{2}{*}{17.68} & 5.52 & \multirow{2}{*}{5.36} & \multirow{2}{*}{0.23} & \multirow{2}{*}{4.36} \\
\hline & 4.5 & & & & 5.19 & & & \\
\hline \multirow{2}{*}{ LabA1 } & 4.7 & \multirow{2}{*}{4.95} & \multirow{2}{*}{0.35} & \multirow{2}{*}{7.14} & 0.6 & \multirow{2}{*}{0.63} & \multirow{2}{*}{0.04} & \multirow{2}{*}{5.66} \\
\hline & 5.2 & & & & 0.65 & & & \\
\hline
\end{tabular}

Appendix C: Characterization tests (dynamic elasticity modulus and capillarity coefficient) of hardened mortar produced in different types of shotcrete equipment

\begin{tabular}{|c|c|c|c|c|c|c|c|c|}
\hline \multicolumn{9}{|c|}{ Response variables (hardened mortar) } \\
\hline Sample ID & $\begin{array}{c}\text { Dynamic } \\
\text { elasticity } \\
\text { modulus (GPa) }\end{array}$ & $\begin{array}{l}\text { Mean } \\
(\mathrm{GPa})\end{array}$ & $\mathrm{SD}(\mathrm{GPa})$ & CV (\%) & $\begin{array}{c}\text { Capillarity } \\
\text { coefficient } \\
\left(\mathrm{g} / \mathrm{dm}^{2} \cdot \mathrm{min}^{1} / 2\right)\end{array}$ & $\begin{array}{c}\text { Mean } \\
\left(\mathrm{g} / \mathrm{dm}^{2} \cdot \mathrm{mi}\right. \\
\left.\mathrm{n}^{1 / 2}\right)\end{array}$ & $\begin{array}{c}\mathrm{SD} \\
\left(\mathrm{g} / \mathrm{dm}^{2} .\right. \\
\left.\min ^{1 / 2}\right)\end{array}$ & CV $(\%)$ \\
\hline \multirow{3}{*}{ E1 } & 10.69 & \multirow{3}{*}{10.48} & \multirow{3}{*}{0.30} & \multirow{3}{*}{2.89} & 6.60 & \multirow{3}{*}{6.60} & \multirow{3}{*}{0.30} & \multirow{3}{*}{4.47} \\
\hline & 10.13 & & & & 6.89 & & & \\
\hline & 10.62 & & & & 6.30 & & & \\
\hline \multirow{3}{*}{ E2 } & 11.08 & \multirow{3}{*}{11.04} & \multirow{3}{*}{0.05} & \multirow{3}{*}{0.43} & 5.78 & \multirow{3}{*}{5.34} & \multirow{3}{*}{0.47} & \multirow{3}{*}{8.75} \\
\hline & 11.06 & & & & 4.85 & & & \\
\hline & 10.99 & & & & 5.40 & & & \\
\hline \multirow{3}{*}{ LabA1 } & 10.72 & \multirow{3}{*}{10.80} & \multirow{3}{*}{0.54} & \multirow{3}{*}{5.01} & 5.04 & \multirow{3}{*}{4.82} & \multirow{3}{*}{0.19} & \multirow{3}{*}{4.00} \\
\hline & 11.37 & & & & 4.74 & & & \\
\hline & 10.30 & & & & 4.68 & & & \\
\hline
\end{tabular}

Appendix D: Characterization tests (mechanical strength and apparent mass density) of hardened mortar produced in different types of shotcrete equipment (Continue...)

\begin{tabular}{|c|c|c|c|c|c|c|c|c|c|c|c|c|}
\hline \multicolumn{13}{|c|}{ Response variables (hardened mortar) } \\
\hline Sample ID & $\begin{array}{c}\text { Flexural } \\
\text { strenght } \\
\text { (MPa) }\end{array}$ & $\begin{array}{r}\text { Mean } \\
(\mathrm{MPa})\end{array}$ & $\begin{array}{c}\text { SD } \\
(\mathrm{MPa})\end{array}$ & $\begin{array}{l}\text { CV } \\
\text { (\%) }\end{array}$ & $\begin{array}{c}\text { Compressive } \\
\text { strenght } \\
\text { (MPa) }\end{array}$ & $\begin{array}{l}\text { Mean } \\
\text { (MPa) }\end{array}$ & $\begin{array}{c}\text { SD } \\
\text { (MPa) }\end{array}$ & $\begin{array}{l}\text { CV } \\
\text { (\%) }\end{array}$ & $\begin{array}{c}\text { Apparent } \\
\text { mass } \\
\text { density } \\
\left(\mathrm{kg} / \mathrm{m}^{3}\right)\end{array}$ & $\begin{array}{c}\text { Mean } \\
\left(\mathrm{kg} / \mathrm{m}^{3}\right)\end{array}$ & $\begin{array}{c}\mathrm{SD} \\
\left(\mathrm{kg} / \mathrm{m}^{3}\right)\end{array}$ & $\begin{array}{l}\text { CV } \\
\text { (\%) }\end{array}$ \\
\hline \multirow{12}{*}{ E1 } & 3.05 & \multirow{12}{*}{3.06} & \multirow{12}{*}{0.17} & \multirow{12}{*}{5.52} & 8.81 & \multirow{12}{*}{7.36} & \multirow{12}{*}{0.95} & \multirow{12}{*}{12.90} & 1700 & \multirow{12}{*}{1752} & \multirow{12}{*}{35} & \multirow{12}{*}{1.98} \\
\hline & 2.89 & & & & 5.94 & & & & 1722 & & & \\
\hline & 3.23 & & & & 7.34 & & & & 1727 & & & \\
\hline & & & & & 6.93 & & & & 1774 & & & \\
\hline & & & & & 7.30 & & & & 1810 & & & \\
\hline & & & & & 7.83 & & & & 1750 & & & \\
\hline & & & & & & & & & 1797 & & & \\
\hline & & & & & & & & & 1718 & & & \\
\hline & & & & & & & & & 1765 & & & \\
\hline & & & & & & & & & 1772 & & & \\
\hline & & & & & & & & & 1721 & & & \\
\hline & & & & & & & & & 1769 & & & \\
\hline
\end{tabular}


Appendix D: Characterization tests (mechanical strength and apparent mass density) of hardened mortar produced in different types of shotcrete equipment (conclusion)

\begin{tabular}{|c|c|c|c|c|c|c|c|c|c|c|c|c|}
\hline \multicolumn{13}{|c|}{ Response variables (hardened mortar) } \\
\hline Sample ID & $\begin{array}{c}\text { Flexural } \\
\text { strenght } \\
(\mathrm{MPa})\end{array}$ & $\begin{array}{c}\text { Mean } \\
(\mathrm{MPa})\end{array}$ & $\begin{array}{c}\text { SD } \\
\text { (MPa) }\end{array}$ & $\begin{array}{l}\text { CV } \\
\text { (\%) }\end{array}$ & $\begin{array}{c}\text { Compressive } \\
\text { strenght } \\
\text { (MPa) }\end{array}$ & $\begin{array}{l}\text { Mean } \\
\text { (MPa) }\end{array}$ & $\begin{array}{c}\text { SD } \\
\text { (MPa) }\end{array}$ & $\begin{array}{l}\text { CV } \\
\text { (\%) }\end{array}$ & $\begin{array}{c}\text { Apparent } \\
\text { mass } \\
\text { density } \\
\left(\mathrm{kg} / \mathrm{m}^{3}\right)\end{array}$ & $\begin{array}{c}\text { Mean } \\
\left(\mathrm{kg} / \mathrm{m}^{3}\right)\end{array}$ & $\begin{array}{c}\mathrm{SD} \\
\left(\mathrm{kg} / \mathrm{m}^{3}\right)\end{array}$ & $\begin{array}{l}\text { CV } \\
\text { (\%) }\end{array}$ \\
\hline \multirow{12}{*}{ E2 } & 1.79 & \multirow{12}{*}{1.96} & \multirow{12}{*}{0.23} & \multirow{12}{*}{11.59} & 6.69 & \multirow{12}{*}{7.15} & \multirow{12}{*}{0.60} & \multirow{12}{*}{8.38} & 1748 & \multirow{12}{*}{1757} & \multirow{12}{*}{20} & \multirow{12}{*}{1.14} \\
\hline & 2.22 & & & & 6.46 & & & & 1746 & & & \\
\hline & 1.88 & & & & 8.18 & & & & 1733 & & & \\
\hline & 2.00 & & & & 7.18 & & & & 1799 & & & \\
\hline & & & & & 7.35 & & & & 1776 & & & \\
\hline & & & & & 7.06 & & & & 1755 & & & \\
\hline & & & & & 6.60 & & & & 1754 & & & \\
\hline & & & & & 6.88 & & & & 1735 & & & \\
\hline & & & & & & & & & 1756 & & & \\
\hline & & & & & & & & & 1745 & & & \\
\hline & & & & & & & & & 1786 & & & \\
\hline & & & & & & & & & 1754 & & & \\
\hline \multirow{12}{*}{ LabA1 } & 2.09 & \multirow{12}{*}{2.18} & \multirow{12}{*}{0.09} & \multirow{12}{*}{3.93} & 5.20 & \multirow{12}{*}{5.12} & \multirow{12}{*}{0.77} & \multirow{12}{*}{15.09} & 1583 & \multirow{12}{*}{1601} & \multirow{12}{*}{14} & \multirow{12}{*}{0.89} \\
\hline & 2.19 & & & & 5.32 & & & & 1584 & & & \\
\hline & 2.26 & & & & 3.69 & & & & 1583 & & & \\
\hline & & & & & 5.08 & & & & 1622 & & & \\
\hline & & & & & 5.38 & & & & 1606 & & & \\
\hline & & & & & 6.02 & & & & 1605 & & & \\
\hline & & & & & & & & & 1595 & & & \\
\hline & & & & & & & & & 1603 & & & \\
\hline & & & & & & & & & 1596 & & & \\
\hline & & & & & & & & & 1596 & & & \\
\hline & & & & & & & & & 1624 & & & \\
\hline & & & & & & & & & 1614 & & & \\
\hline
\end{tabular}

\section{Gabriela Cechin}

Escola de Engenharia | Universidade Federal do Rio Grande do Sul | Av. Osvaldo Aranha, 99, Prédio do Castelinho - NORIE, Centro | Porto Alegre - RS - Brasil | CEP 90035-190 | Tel.: (51) 3308-3518 Ramal 51 | E-mail: gabrielacechin@gmail.com

\section{Carina Mariane Stolz}

Instituto de Ciências Exatas e Tecnológicas | Universidade Feevale | Rodovia RS-239, Vila Nova | Novo Hamburgo - RS - Brasil | CEP 93525-075 | Tel.: (51) 3586-8800 | E-mail: carimstolz@yahoo.com.br

\section{Ângela Borges Masuero}

Escola de Engenharia | Universidade Federal do Rio Grande do Sul | Tel.: (51) 3308-3518 | E-mail: angela.masuero@ufrgs.br

\section{Revista Ambiente Construído}

Associação Nacional de Tecnologia do Ambiente Construído

Av. Osvaldo Aranha, 99 - 3o andar, Centro

Porto Alegre - RS - Brasil

CEP 90035-190

Telefone: +55 (51) 3308-4084

Fax: +55 (51) 3308-4054

www. seer. ufrgs. br/ ambienteconstruido

E-mail: ambienteconstruido@ufrgs.br

This is an open-access article distributed under the terms of the Creative Commons Attribution License. 